\title{
Tourism Destination Development from the Perspective of Tourism Functional Area Planning
}

\author{
Pranav B San \\ Department of Architecture, TKM College of Engineering, Kollam, India \\ pranavbsan17@gmail.com
}

\begin{abstract}
Tourism is one of the fastest growing sector which acts as an engine of growth in many countries. Tourism has played major role in accelerating economic growth of Kerala, popularly known as God's Own Country. The concept of Responsible Tourism was introduced as Kerala had an ideal setting of abundant natural and skilled human resources, strong local self-governments and a very responsive tourism industry. This concept of tourism includes the triple bottom line-Economic, social and environmental responsibility. This paper explores Total destination development implemented to generate greater economic benefits and enhance well being of local communities, conserving natural resources and protecting the environment, implemented through Responsible Tourism planning. The Neyyar River is $56 \mathrm{~km}$ long river which flows through the Thiruvananthapuram district of Kerala in India. Kallikad panchayath is the area where the Neyyar dam and other tourist destinations are located. This paper is based on planning and developing this less developed area, which has immense potential to develop as water based tourism destination. The study focused on destination development of Kallikad panchayath, situated at the banks of Neyyar River, to bring positive social, economic and environmental impacts.
\end{abstract}

Keywords: Kerala, Responsible tourism, Sustainable tourism, Community participation

\section{Introduction}

Tourism is one of the world's largest and fastest growing industries in this era. Modern tourism is closely linked to development and led to growing number of new destinations. Traditionally development can be defined in terms of economic development. But today development has become much more comprehensive in meaning, embracing many dimensions such as social, cultural, environmental, equity dimensions etc.

Kerala state, popularly known as God's Own Country“ (2000) is one of the most popular tourist destinations in the country. In 2001, Kerala launched Tourism Vision 2025 and it aimed to develop Kerala into an up-market tourist destination and to make use of tourism for socio- economic development in a sustainable manner, without harming the state's environment, heritage and culture.' In 2007, Kerala government adopted - Responsible Tourism (RT) as the focus of the tourism policy.

The main Objective of Responsible Tourism is to create better places for people to live and visit. Responsible Tourism means that tourist operators, hoteliers, governments, local people and tourists take responsibility, take action to make tourism more sustainable. Responsible Tourism can benefit to the local population through Total Destination Development of the area. Tourism development will act as a promoter for this Destination Development. Destination development is the process of coordination and development of amenities, facilities, products, services and to support host communities to deliver quality experiences for visitors and enhance resident's well-being. Total destination development means overall development through enhancement of Social life and the Environment. The project is based on evolving strategies for Destination development through Responsible Tourism planning in the selected destination
The two major wildlife sanctuaries in Thiruvananthapuram districts are Neyyar and Peepara wildlife sanctuaries. Neyyar is situated $30 \mathrm{~km}$ east of Thiruvananthapuram district. Neyyar wildlife sanctuary was formed in 1958 and it is covered with 12,000 hectares of rich vegetation. Tropical evergreens, mixed deciduous and southern hill make this sanctuary an ideal place for the tourists. Animals like elephants, gaur, sloth bear, Nilgiri tahr, Nilgiri langur, etc, and a variety of reptiles including the python, viper, flying snake etc inhabit this forestland. Ecotourism activities at present in this sanctuaries is limited to conducting nature camps, visiting crocodile rehabilitation center, lion safari park, deer rehabilitation center, and boating in the reservoirs in both the sanctuaries. Very few groups mainly foreign tourists only arrive at present availing the trekking programs. To make more and more people interact and understand the forests, their importance, and their sustainable management for present and future generations, tourism related economic programs should be improved in the area.

\section{Responsible Tourism Concept}

Responsible tourism emerged in the 1980s and in terms of interpretation and application in, tourism is well carried by the following: Responsible tourism is not a tourism product or brand. It represents a way of doing tourism planning, policy and development to ensure that benefits are optimally distributed among impacted populations, governments, tourists and investors.

Responsible tourism is an ethical approach that is not to be misunderstood as a new type of alternate. It is a principle that can and must apply to all forms of tourism, including small and large scale, domestic and international, mass and individualized, and culturally and environmentally-oriented tourism. According to Goodwin, it is an approach that aims not only at tourism planners and managers in the development process of tourism but also at everyone 
involved in a tourism product, ranging from the host populations, local governments and businesses, to the tour

operators and the tourists visiting a destination.

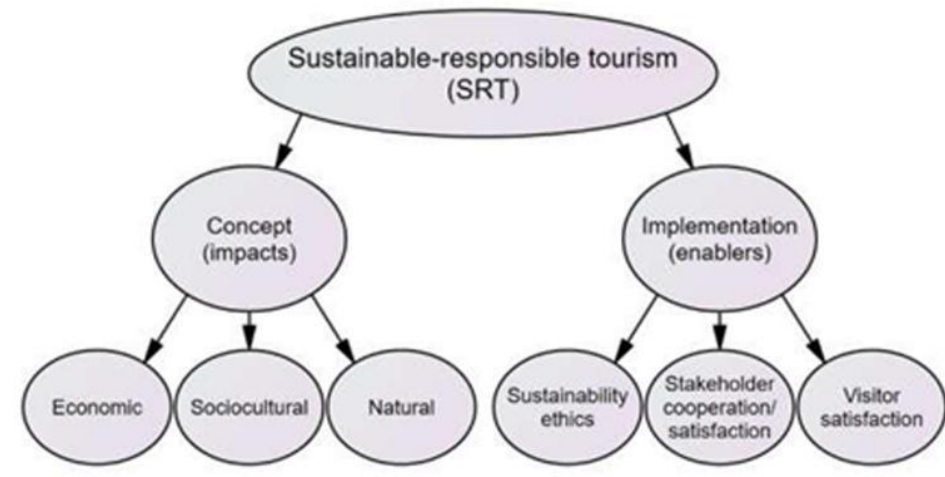

Figure 1: Concept of Sustainable tourism

\section{Objectives and Scope}

The aim of the study is to develop strategies for Destination Development through Responsible Tourism planning initiatives at Neyyar.

- To study the relevance of Responsible Tourism and identify parameters required to enhance the quality of environment and Quality of life.

- To study regional priorities and existing conditions of Neyyar and identify issuesand potentials

- To analyse the infrastructure and other development needs for supporting and substantiating responsible tourism at Neyyar.

- To evolve strategies for destination development through Responsible Tourism planning based on the identified parameters.

The study will help to introduce responsible tourism in Kallikad panchayath and it may boost the destination as a responsible tourist spot

\section{Methodology}

The research will carry out in three stages, preparation \& collection of background materials, fieldwork \& site study and data analysis \& formulation of strategies. The major tasks in the first stage is to narrow down the research topic, read relevant academic materials, design the detailed research process, select appropriate methodologies, design interview question lists and a questionnaire.

In the second stage fieldwork is conducted. Major tasks in this stage are interviews, surveys, on-site observation in the city, and search for relevant secondary data from concerned authorities. The applicability of responsible tourism in the area is analyzed and further strategies and suggestions can beevolved by analyzing the data.

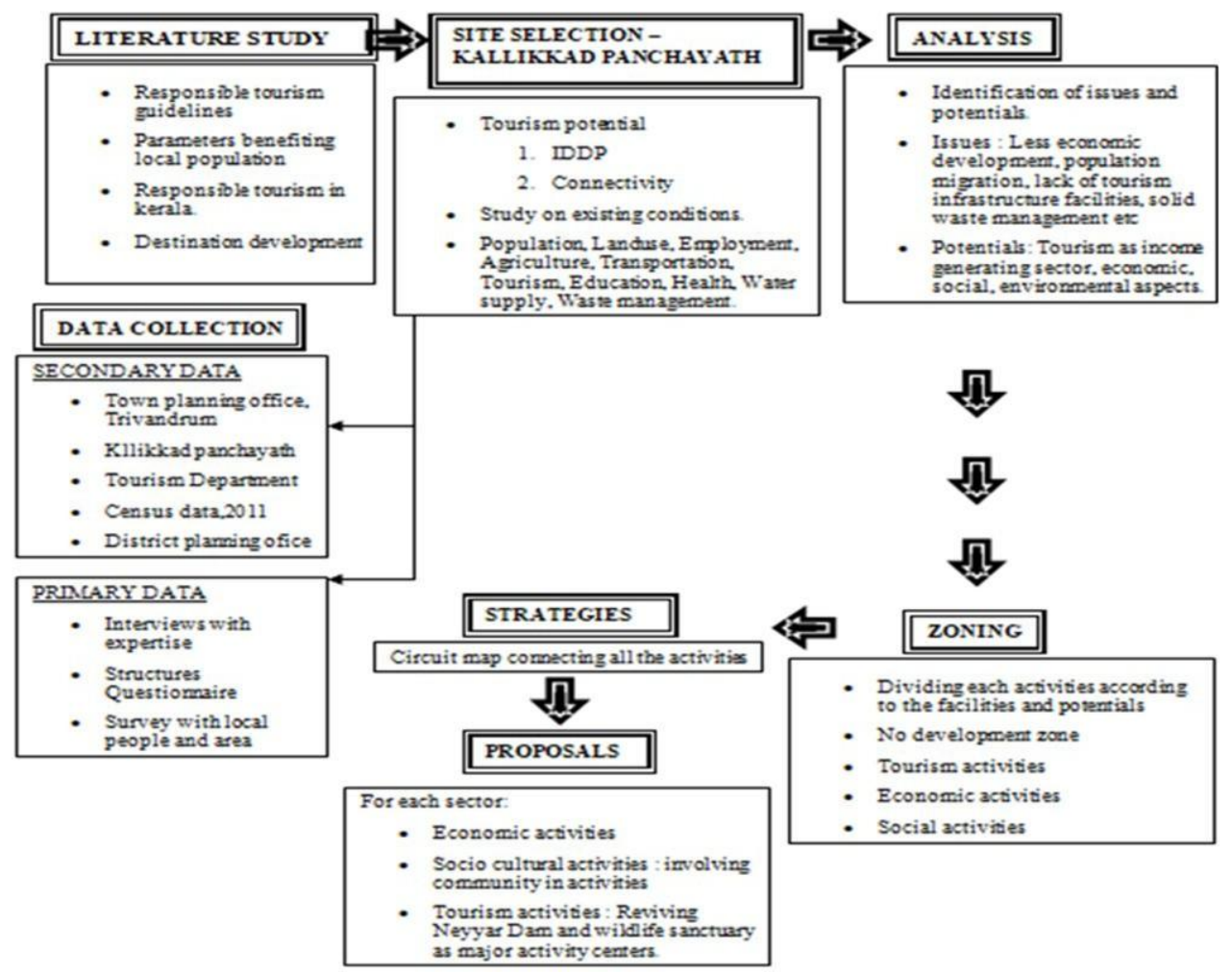

Figure 2: Methodology of the Study

Volume 8 Issue 10, 2021 


\section{Study Area}

The study area consists of Kallikkad, which is about $30 \mathrm{kms}$ west of Trivandrum city. Kallikkad is a village in Thiruvananthapuram District in Kerala. The Neyyar Dam area is situated in Kallikkad panchayath. The panchayath consists of 13 wards which includes neyyar dam as one of its ward. All the 13 wards are taken as the study area. The area is surrounded by Neyyar wild life sanctuary and Agasthyarkoodam mountains, which is a part of western ghats at the east, Peepara wild life sanctuary at the north, Kattakada town at the west and Neyyatinkara at south Kallikkadu panchayath is connected to Nedumangad Highway at Kallikkadu ward. The nearest airport is Trivandrum International Airport which is located $29.5 \mathrm{Kms}$ away from Kallikkadu. The nearest railway station is Trivandrum central railway station which is about $23.8 \mathrm{kms}$ away from Kallikkadu.There are so many Kani settlements in this panchayath. Vlavetti is one of them. This panchayath have prominent historical and cultural backgrounds. The travancore king, Marthanda varma's plight against Ettuveetil pillas were through the mountain paths of kallikkadu.

\section{Analysis of the Existing Status}

On analyzing the existing population density variation within the study area, it is seen that a marginal decreasing growth rate was found in panchayath level. The population density in the area is also less. Migration levels are seen in the area due to lack of employment and services. The potential tourism sector is still underutilized here. A marginal decrease can be seen in the number of households from 2001 to 2011. These depicts decrease in population due to migration and other factors.

The number of male population in the area is 4605 and the number of female population is 4808 . The sex ratio in the study area is 1028 . The literacy rate in the area is $89.6 \%$ out of which almost $50 \%$ are males and 50

$\%$ females.

The amount of marginal workers are the highest in the area which means a huge amount of people stays unemployed throughout half of the year. It is a good opportunity for those people to get involved in tourism related activities by introducing Responsible tourism. From the datas, it is evident that the male working population is higher than the female working population.

From an online survey conducted on 50 respondents from the study area, almost $70 \%$ of the working population present there are men. Almost $76 \%$ of the female populations were willing to go for work to urban areas but the main challenges were lack of job opportunities and distance. The major working population in the study area are marginal workers and other woring category especially urban labourers and daily wagers. From the survey, $88 \%$ of the respondents were ready to do jobs related to tourism activities which is a potential factor for implementing responsible tourism in the area.
Karamana River with two reservoirs at Peppara and Aruvikkara is the main surface water source for the area The Neyyar river basin is the southernmost basin of the State lying adjacent to the Karamana river basin. The basin has an area of 497 sq.km. The water resource of the basin is assessed as $229 \mathrm{Mm} 3$. The Neyyar irrigation project is the major existing irrigation project in the area.

Coconut cultivation is the highest crop cultivation in the study area. More than $4000 \mathrm{Ha}$ land were used for coconut cultivation. Other major crops includes tapioca, pepper, plantain, jackfruit, mango, paddy etc.The abundance in coconut cultivation can promote coir retting and other coconut products which can be a source of income for the people which can trigger the possibilities of Responsible Tourism in the area.

Basic infrastructure facilities are available and adequate considering the population of the area.Lack of enough streetlights has been reported at some areas.

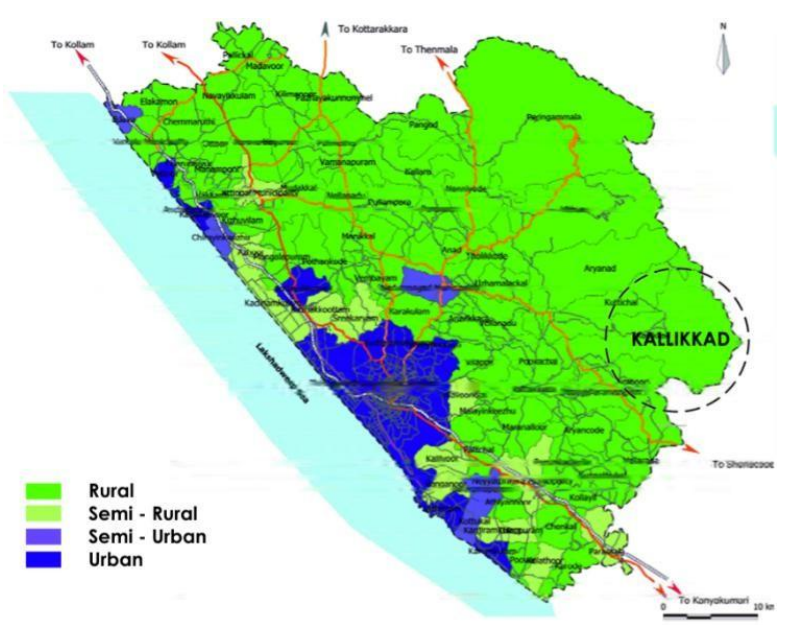

Figure 3: Location of Kallikad in Trivandrum district

Table 1: Category of workers in Kallikad panchayath

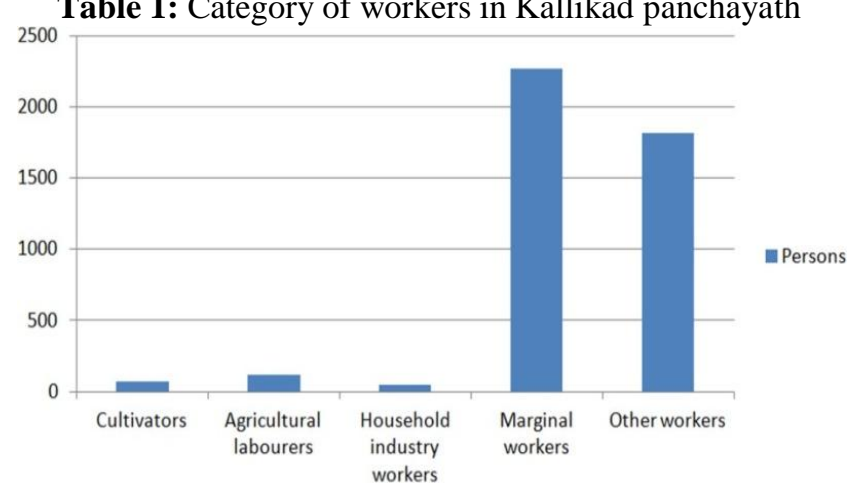

\section{Area Preparedness}

This study was done in order to know whether the area is ready to face such a project implementation. It was done to know how much prepared is the area or to know whether the area is ready to accept the changes brought up by Responsible tourism in the area.

An online and a telephonic survey was conducted among the natives in order to gather the data required to analyze the willingness of the area. The online survey was based on 50 respondents while the telephonic survey was based on 10 
respondents. The major questions involved were regarding the workforce, employment pattern, knowledge on responsible tourism, acceptance of tourism related employment, willingness to participate.

The result was that most of the people are aware of the tourism potentiality of the area. From the survey, alomst

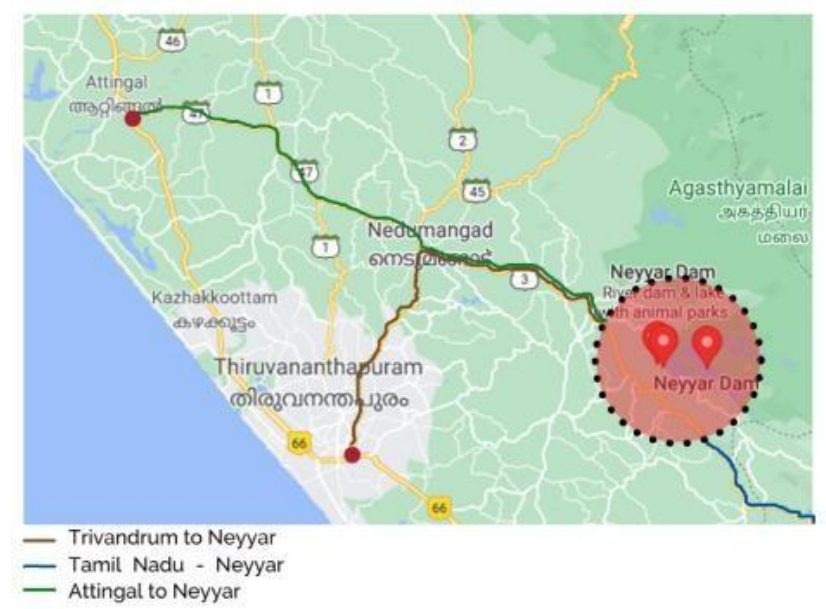

Figure 4: 2 Map showing approach roads to the Study Area from the city and outskirts

\section{SWOT Analysis}

\section{Strengths}

- Nearness to Capital City

- Agasthyamalai peak and Neyyar Wildlife Sanctuary nearby

- Adjacent to peppara WLS and Kallikkadu mundanthurai Tiger reserve

- Existing Neyyar Tourism spots and adventures

- Unexplored Neyyar-Poovar waterway

- Neyyar Dam and irrigation project

- Preserved ecological area

- $\quad$ Large number of marginal workers

\section{Weaknesses}

- Lack of adequate tourism infrastructure

- Absence of an interpretation program

- Low number of foreign tourists

- Poor and improper maintenance

- Lack of new and innovative tourism practices

\section{Opportunities}

- Boating, Lion safari park, Deer park, Crocodile Rehab

- Possibilities of Responsible tourism practices which could be implemented in the present occupations in the area

- $\quad$ Trekking, Meenmutty Falls

- Nature education

- Eco tourism and community participation

\section{Threats}

- Expansion of cultivation within the sanctuary

- Crocodile - Man conflict

- Improper waste management

- Migration for better employment and opportunities
$70 \%$ of the people are willing to co-operate with Responsible Tourism in the area. Most of the hotels and resorts of the area agreed to buy groceries from local people. It can trigger the possibilities of RT in the area. Local art forms and crafts should be showcased in the area. A platform to display these forms will increase the possibilities of RT in the area.

\section{Suggestions}

- The residents and the tourists should be made aware of the possibilities of responsible tourism in the area.

- Government should efficiently involve in the development of responsible tourism behavior in the area.

- Small scale industries and local businesses promoting responsible tourism should be encouraged in the area.

- More resource protection activities should be introduced in the ecotourism project.

- More steps should be taken from the government's side to promote the responsible tourism activities in the area.

- Effective waste management should be introduced in concerned area to reduce pollution

- Adequate tourism infrastructure facilities should be provided

\section{Conclusion}

Tourism planning is relevant for the development and protection of an area. Tourism Planning can focus at the national, regional, or even at a destination or a site level. A combination of all aspects will achieve most desired outcome. Tourism planning at any level can be aimed giving special attention understanding the spatial needs and fabric. Responsible Tourism initiative was successfully implemented to achieve sustainable Tourism planning. So, while developing a tourism potential destination, the tourism sector can play the key role of a promoter in development of that area. The study significantly has a positive relationship between responsible tourism and Neyyar. It was concluded that efficient destination development and more employment opportunities for local residents were the key elements to promote the responsible tourism in this study area. Through peoples participation, more economic and social activities can be implemented with support of government and private agencies. Thus, the area can be developed into a beautiful destination following the three pillars of sustainability and can be extended to tourists from all over the world.

\section{References}

[1] Airey, D., Tribe, J. \& others. (2019). An international handbook of tourism education. Centre for Peace research and Peace education of the Klagenfurt university/Austria in cooperation with World

$$
\text { tourism organization }
$$

(UNWTO).Austria: Routledge.

[2] Blanke, Jennifer. \& and Chiesa, Thea ,.(2013).The Travel \& Tourism Competitiveness Report 2013. Reducing Barriers to Economic Growth and Job 
Creation. Geneva: World Economic Forum.

[3] Budeanu, A. (2005). Impacts and responsibilities for sustainable tourism: a tour operator's perspective. London: King's College.

[4] Githui, D. M. (2019). Responsible Tourism and Hotel Management: An Empirical Analysis of the Ethical Dimensions in Tourism and Hospitality Industry in Kenya. American International Journal of Contemporary Research, 3(6), 1-13.

[5] Kerala State Land Use Board. (2013). Natural Resources Data Bank Thiruvananthapuram.

[6] Kerala State Pollution Control Board. (February 2019). Karamana River Action Plan. Trivandrum.

[7] Goodwin, H. \& Font, X. (2012). From mass to responsible tourism: the Turkish experience. Tourism Management, 2(1), 4-61.

[8] Goodwin, H. (2011). Taking responsibility for tourism (Chapter 6): Goodfellow Publishers Limited Woodeaton.

[9] Hall, C. M., Gossling, S., \& Scott, D. (Eds.). (2015). The Routledge handbook of tourism and sustainability: Routledge.

[10]Report on Kerala Panchayat Level Statistics- 2011, Thiruvananthapuram.

\section{Author Profile}

Pranav B San received B.Arch (Bachelor of Architecture) degree from NRM School of Architecture in 2019. Now, pursuing M. Plan (Urban Planning) degree in TKM College of Engineering, Kollam (2019 -21 batch). 